\title{
The effect of gratitude training on the balance affect: the effort of increasing subjective well-being of the poor resident in surakarta
}

\author{
Fadjri Kirana Anggraini \\ Department of Psychology, Faculty of Medicine \\ Sebelas Maret University \\ Surakarta, Indonesia \\ fadjri.kirana@gmail.com
}

\author{
Tri Rejeki Andayani \\ Department of Psychology, Faculty of Medicine \\ Sebelas Maret University \\ Surakarta, Indonesia \\ menikpsy@yahoo.com
}

\begin{abstract}
- this study aims to find out the effect of gratitude training on the balance affect or the change of affect caused by the increase of positive affect which was relatively constant and the decrease of negative affect. This quasi experiment study with pretest posttest control group design involving 10 subjects (experiment) and 9 subjects (control) of poor resident in Surakarta with the low score of subjective well-being. Data were collected by Scale of Positive and Negative Experience (SPANE) in which balance affect was the difference between positive and negative effects. Data were analyzed by independent sample ttest. The result of the study showed that the gratitude training increased the balance affect relatively constant (t.valuepretestposttest 3,133> t.table 1,740;p<0,05 and t.valuepretest-follow up 2,728> t.table 1,740; $<<0,05)$. However, if each affect was examined deeper, the gratitude training was shown to increase the positive affect relatively constant (t.valuepretest-posttest 2,558> t.table2, 110; $p<0$, 05; t.valuepretest-follow up 2,457> t.table 2,110; $p<0,05)$, at the other side there was no significant change in negative affect (t.valuepretest-posttest $0,717<$ t.table 2,110; p>0, 05; t.valuepretest-follow up 1,837 < t.table 2,110; p >0, $05)$. In other words, the positive influence of gratitude training on the balance affect of the poor resident in Surakarta was caused by significant increasing of positive affect that was relatively constant.
\end{abstract}

Keywords—gratitude training; balance affect; the poor resident

\section{INTRODUCTION}

Diner, et al. explained that lower income in developing and poor countries gave an effect on subjective wellbeing [1]. Subjective well-being referred to the individual's affective and cognitive evaluation of their life [2]. Further, Diener explained that compared the everyday experiences of positive and negative effects, those components would predicted the level of subjective well-being [3]. Gratitude as one of the main predictor of subjective well-being was interconnected both as affective trait and as affective state [4]. Increasing in positive affect was proven by the experiments of gratitude toward individuals [4]. Emmons and McCullogh found that intervention through gratitude could increase the positive affect that was component of subjective wellbeing [5]. This study specifically purposed to know the effect of gratitude training on the affect component of subjective wellbeing (referred to balance affect) as the effort of increasing subjective well-being of the poor resident in Surakarta

\section{METHOD}

\section{A. Partisipants}

The study population was the poor resident in Surakarta, that was, individuals who fulfilled at least 9 of the 14 criteria as the poor. Samples were taken using purposive incidental sampling. Subjects were determined based on the Scale of Positive and Negative Experience (SPANE) screening as well as the pretest. SPANE was constructed by Diener and BiswasDiener to measure the individual's affect judgment of mood and emotion felt in life. SPANE used a Likert model scoring system consisted of 12 items and 5 response scales with categorization from 1 (very rarely or almost never) up to 5 (very often or always), divided into 2 subscales that measure positive and negative affects [6]. Both positive and negative scales were calculated separately because they were two separate affective variables.

Positive Experience (SPANE-P) had range from 6 to 30 showed the positive affect level felt by the individual, as well as the negative score (SPANE-N) that indicated the level of negative affect which was felt by the individual. The total score was obtained by reducing the positive score with negative score (The Balance of Positive and Negative Experience), the score ranged from -24 to 24 [6]. This instrument used a Likert scale type and had a reliability coefficient ranging from 0.83 $0.86[6]$.

The homogeneity of subjects was maintained by determining the characteristics, those were:

- Medium to low level of balance affect.

- Are married

Marriage was an important factor of subjective well-being so the difference of marriage status could be secondary variable that make the ineffective of gratitude training [7].

- Female

The position of mother was as a central figure to develop the personality and attitudes of children. Children learned 
through imitation and mother provided social stimulation for children development. Therefore, the selected study's subjects were female.

- Never got gratitude training.

The process of determining the subject in this study was done through the screening of SPANE scale adaptation as a pretest. Researcher then choose subjects with moderate to low level of balance affect and divided them into experiment and control groups randomly. It was expected to obtain two relatively homogeneous subjects of balance affect.

\section{B. Design of Study}

Quasi-experiment study used the pretest-posttest control group design model. Measurements were taken twice, i.e. before (pretest) and after (posttest and follow up) treatment of two groups (experiment and control group). Pretest was done at the same time as a screening to get the score of balance affect.

Based on the pretest results, the selected sample will be randomly divided into two groups; experiment and control groups. Selection of subjects in each group was done randomly as a control of proactive history [8]. Each group consisted of 10 people maximally. Effective teams can be formed with an amount of 2 to 25 people or less than 10 people in each group [9]. Sugiyono explained that a simple experiment study using 10-20 subjects in each group, for both experiment and control groups [10]. After treatment of the experiment group, remeasurement of balance affect as posttest and measured follow up 2 weeks afterwards by using the same measuring instrument. The illustrative symbols of this design were as follows:

\begin{tabular}{|c|c|c|c|c|c|}
\hline $\begin{array}{l}\text { R } \\
(\mathrm{KE})\end{array}$ & $\begin{array}{c}\text { Measure } \\
\text { ment }(\mathrm{O} 1) \\
\text { (pretest) }\end{array}$ & $\begin{array}{c}\text { Treat } \\
\text { ment } \\
(\mathrm{X})\end{array}$ & $\Rightarrow$ & $\begin{array}{l}\text { Measure } \\
\text { ment } \\
(\mathrm{O} 2) \\
\text { (posttest) }\end{array}$ & $\begin{array}{c}\text { Measurem } \\
\text { ent (O3) } \\
\text { (follow } \\
\text { up) }\end{array}$ \\
\hline $\begin{array}{l}\mathrm{R} \\
(\mathrm{KK})\end{array}$ & $\begin{array}{l}\text { Measure } \\
\text { ment }(\mathrm{O} 1) \\
(\text { pretest })\end{array}$ & $\square$ & $\begin{array}{r}\text { Mea } \\
\mathrm{m} \\
(\mathrm{C} \\
\text { pos }\end{array}$ & & $\begin{array}{l}\text { Measure } \\
\text { ment } \\
(\mathrm{O} 3) \\
\text { (follow up) }\end{array}$ \\
\hline
\end{tabular}

Fig 1 Pretest-Posttest Control Group Design

The implementation procedure of the study to be carried out was as follows:

- Providing a pretest scale of Positive and Negative Experience (SPANE) that was constructed by Diener and Biswas-Diener [6] in the subject group. Then the subject was classified according to the degree of balance affect based on the obtained score.

- Group subjects that had a moderate to low level of balance affect were assigned to the control and experiment groups randomly. The experiment group was taken from the subject who filled out the informed consent to follow the entire set of gratitude training.

- Giving treatment to the experiment group as much as 4 times, while the control group was not given treatment. The training was administered by the facilitator and assisted by the co-facilitator in Semanggi RT 4 / RW VI.
- Providing posttest with Scale of Positive and Negative Experience (SPANE) in both control and experiment group.

- $\quad$ Providing follow up with Scale of Positive and Negative Experience (SPANE) in both control and experiment group.

- Analyzing the results of treatment to determine the difference effect of control and experiment groups to the level of balance affect of the poor resident.

\section{Instrument Analysis}

The adapted SPANE instrument needed to be tested for its validity and reliability. Therefore, prior to the first use, an instrument trial would be conducted including:

- Validity Test

\section{- Scale}

Measurement of scale validity test in this study used content validity test or content validity, through professional judgment review done by supervisors. Scale in this study would be tested its discriminant items by using product moment correlation technique from Pearson with the help of computer statistic program SPSS for MS Windows version 21.

- $\quad$ Gratitude Training Handout

Measurement of handout validity test in this gratitude training used content validity, through professional judgment reviewed by supervisor and evaluation through handout tryout.

- Reliability Test

Reliability test in this study was done by calculating Cronbach's Alpha coefficient of instrument used. Calculation of scalability test was calculated by using SPSS statistical program for MS Windows version 21.

\section{Data Analysis}

Data analysed by using assumption test and hypotesis test

- Assumption Test

\section{- Normality Test}

The normality test was performed to determine whether the sample taken as the subject fulfilled the criteria of distribution / normal distribution or not [10].

\section{- $\quad$ Test of Equality of Variance}

Non-variant data or homogeneous data were eligible for the Independent Sample T Test [11].

- Hypothesis Test

The hypothesis in this study would be tested by using uncorrelated data/independent sample t-test and the calculated score was called gain score which was difference between pretest and posttest score [8]. This analysis was performed when the relevant data fulfilled the assumption test. 


\section{RESULT}

\section{A. Pretest, Posttest, and Follow Up Result}

The pretest used the obtained data during screening. Posttest was done shortly after experiment and follow up was done 2 weeks after treatment. The data in this measurement is the balance affect score. This score is the total SPANE score before the experiment (pretest), shortly after the experiment (posttest), and 2 weeks after the experiment (follow up). In addition to balance affect, SPANE generates positive and negative affect.

TABLE I. BALANCE AFFECT SCORE OF EXPERIMENT GROUP

\begin{tabular}{|c|c|c|c|c|c|c|}
\hline \multirow{2}{*}{$\begin{array}{c}\text { Su } \\
\text { bje } \\
\text { ct }\end{array}$} & \multicolumn{7}{|c|}{ Measurement } \\
\cline { 2 - 7 } & \multicolumn{2}{|c|}{ Pretest } & \multicolumn{2}{|c|}{ Posttest } & \multicolumn{2}{c|}{ Follow Up } \\
\cline { 2 - 7 } & Score & Category & $\begin{array}{c}\text { Scor } \\
\text { e }\end{array}$ & Category & $\begin{array}{c}\text { Scor } \\
\text { er }\end{array}$ & Category \\
\hline 1 & -1 & Moderate & 11 & High & 8 & High \\
\hline 2 & 4 & Moderate & 8 & High & 10 & High \\
\hline 3 & 3 & Moderate & 12 & High & 10 & High \\
\hline 4 & -2 & Moderate & 1 & Moderate & 12 & High \\
\hline 5 & 7 & Moderate & 10 & High & 5 & Moderate \\
\hline 6 & 6 & Moderate & 7 & Moderate & 6 & Moderate \\
\hline 7 & 6 & Moderate & 9 & High & 14 & High \\
\hline 8 & -9 & Low & -6 & Moderate & -9 & Low \\
\hline 9 & 0 & Moderate & 8 & High & 17 & High \\
\hline 10 & 7 & Moderate & 11 & High & 9 & High \\
\hline Me & 2,1 & & 7,1 & & 8,2 & \\
An & & & & & & \\
\hline
\end{tabular}

TABLE II. BALANCE AFFECT SCORE OF CONTROL GROUP

\begin{tabular}{|c|c|c|c|c|c|c|}
\hline \multirow{2}{*}{$\begin{array}{c}\text { Subj } \\
\text { ect }\end{array}$} & \multicolumn{7}{|c|}{ Measurement } \\
\cline { 2 - 7 } & \multicolumn{2}{|c|}{ Pretest } & \multicolumn{2}{|c|}{ Posttest } & \multicolumn{2}{c|}{ Follow Up } \\
\cline { 2 - 7 } & Score & Category & Score & Category & Score & Category \\
\hline 1 & 5 & Moderate & 6 & Moderate & 8 & High \\
\hline 2 & 4 & Moderate & 2 & Moderate & -1 & Moderate \\
\hline 3 & 3 & Moderate & 0 & Moderate & 0 & Moderate \\
\hline 4 & -6 & Moderate & -2 & Moderate & -4 & Moderate \\
\hline 5 & 7 & Moderate & 9 & High & 8 & High \\
\hline 6 & 7 & Moderate & 4 & Moderate & 6 & Moderate \\
\hline 7 & 5 & Moderate & 4 & Moderate & 3 & Moderate \\
\hline 8 & 6 & Moderate & 10 & High & 4 & Moderate \\
\hline 9 & -2 & Moderate & 0 & Moderate & 3 & Moderate \\
\hline Me & 3,2 & & 3,67 & & 3 & \\
An & & & & & & \\
\hline
\end{tabular}

TABLE III. POSITIVE AFFECT SCORE OF EXPERIMENT AND CONTROL GROUP

\begin{tabular}{|c|c|c|c|c|c|c|}
\hline \multirow{2}{*}{$\begin{array}{c}\text { Subj } \\
\text { ect }\end{array}$} & \multicolumn{2}{|c|}{ Experiment Measurement } & \multicolumn{3}{c|}{$\begin{array}{c}\text { Control } \\
\text { Measurement }\end{array}$} \\
\cline { 2 - 7 } & $\begin{array}{c}\text { Pre } \\
\text { test }\end{array}$ & $\begin{array}{c}\text { Post } \\
\text { test }\end{array}$ & Follow Up & Pretest & $\begin{array}{c}\text { Post } \\
\text { test }\end{array}$ & $\begin{array}{c}\text { Follow } \\
\text { Up }\end{array}$ \\
\cline { 2 - 7 } & Score & Score & Score & Score & Score & Score \\
\hline 1 & 19 & 29 & 24 & 24 & 23 & 25 \\
\hline 2 & 20 & 25 & 24 & 19 & 19 & 18 \\
\hline 3 & 23 & 29 & 26 & 23 & 17 & 17 \\
\hline 4 & 20 & 22 & 24 & 16 & 20 & 19 \\
\hline 5 & 21 & 24 & 22 & 23 & 26 & 26 \\
\hline 6 & 24 & 23 & 23 & 24 & 20 & 24 \\
\hline 7 & 25 & 25 & 30 & 22 & 22 & 20 \\
\hline 8 & 17 & 17 & 15 & 22 & 24 & 20 \\
\hline 9 & 20 & 26 & 27 & 18 & 15 & 16 \\
\hline
\end{tabular}

TABLE III CONT

\begin{tabular}{|c|c|c|c|c|c|c|}
\hline 10 & 24 & 27 & 24 & & & \\
\hline $\begin{array}{c}\text { Me } \\
\text { an }\end{array}$ & 21,3 & 24,7 & 23,9 & 21,22 & 20,67 & 20,56 \\
\hline
\end{tabular}

TABLE IV. NEGATIVE AFFECT SCORE OF EXPERIMENT AND CONTROL GROUP

\begin{tabular}{|c|c|c|c|c|c|c|}
\hline \multirow{2}{*}{$\begin{array}{c}\text { Subj } \\
\text { ect }\end{array}$} & \multicolumn{2}{|c|}{ Experiment Measurement } & \multicolumn{3}{c|}{$\begin{array}{c}\text { Control } \\
\text { Measurement }\end{array}$} \\
\cline { 2 - 7 } & $\begin{array}{c}\text { Pre } \\
\text { test }\end{array}$ & $\begin{array}{c}\text { Post } \\
\text { test }\end{array}$ & $\begin{array}{c}\text { Follow } \\
\text { Up }\end{array}$ & $\begin{array}{c}\text { Pre } \\
\text { test }\end{array}$ & $\begin{array}{c}\text { Post } \\
\text { test }\end{array}$ & $\begin{array}{c}\text { Follow } \\
\text { Up }\end{array}$ \\
\cline { 2 - 7 } Score & Score & Score & Score & Score & Score \\
\hline 1 & 20 & 18 & 16 & 19 & 17 & 17 \\
\hline 2 & 16 & 17 & 14 & 15 & 17 & 19 \\
\hline 3 & 20 & 17 & 16 & 20 & 17 & 17 \\
\hline 4 & 22 & 21 & 12 & 22 & 22 & 23 \\
\hline 5 & 14 & 14 & 17 & 16 & 17 & 18 \\
\hline 6 & 18 & 16 & 17 & 17 & 16 & 18 \\
\hline 7 & 19 & 16 & 16 & 17 & 18 & 17 \\
\hline 8 & 26 & 23 & 24 & 16 & 14 & 16 \\
\hline 9 & 20 & 18 & 10 & 20 & 15 & 13 \\
\hline 10 & 17 & 16 & 15 & & & \\
\hline $\begin{array}{c}\text { Me } \\
\text { an }\end{array}$ & 19,2 & 17,6 & 15,7 & 18 & 17 & 17,56 \\
\hline
\end{tabular}

The balance affect score difference between positive and negative affect between experiment and control group can also be seen in this figure:

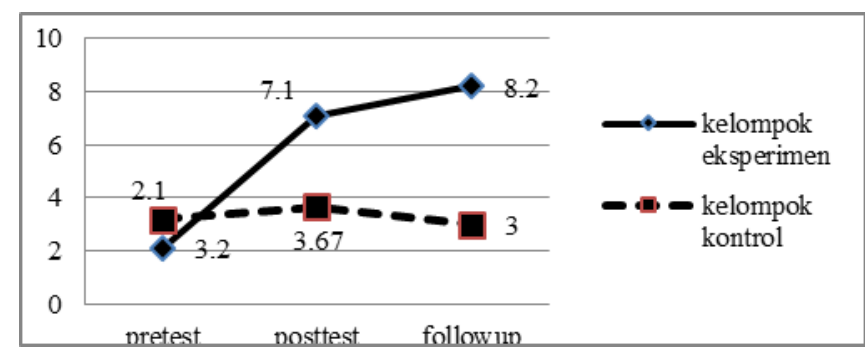

Fig. 2. Average Score of Balance Affect in Experiment and Control Group

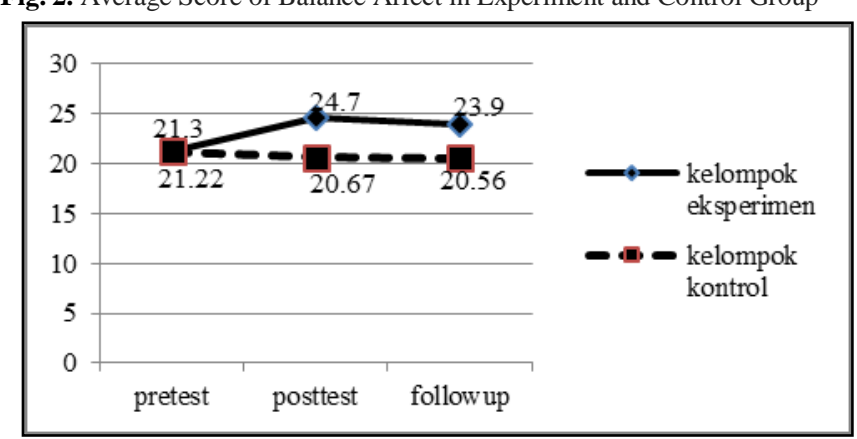

Fig. 3. Average Score of Positive Affect in Experiment and Control Group

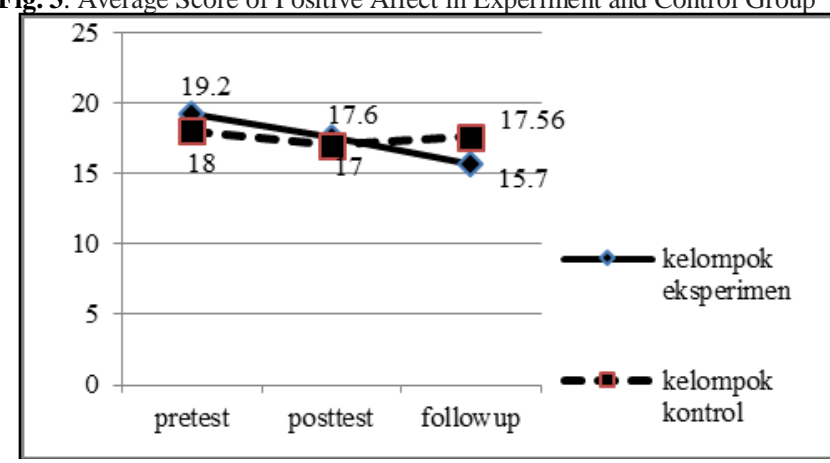

Fig. 4. Average Score of Negative Affect in Experiment and Control Group 
Figure 2 above shows that in the experiment group there is an increasing balance affect compared to that of the control group after the treatment (posttest and follow up). Figure 3 shows that the experiment group experienced an increasing in positive affect compared to that of the control group after training (posttest and follow up) and both groups experienced less noticeable negative affect as seen in Figure 4.

Furthermore, the gained score of pretest, posttest, and follow up in both experiment and control groups are hypothesis tested. Gained score is the difference of score between two measurement times. Thus, the plus and minus signs of the difference value indicates a change with a decreasing (minus) and with an increasing (plus) score from pretest to posttest, pretest to follow-up, or posttest to follow-up.

TABLE V. GAIN SCORE OF BALANCE AFFECT IN EXPERIMENT AND CONTROL GROUP

\begin{tabular}{|c|c|c|c|c|c|c|}
\hline \multirow{2}{*}{$\begin{array}{c}\text { Sub } \\
\text { ject }\end{array}$} & \multicolumn{3}{|c|}{ Gain Score Experiment } & \multicolumn{3}{c|}{ Gain Score Control } \\
\cline { 2 - 7 } & $\begin{array}{c}\text { Pretest- } \\
\text { Posttest }\end{array}$ & $\begin{array}{c}\text { Pretest- } \\
\text { Follow } \\
\text { Up }\end{array}$ & $\begin{array}{c}\text { Posttest- } \\
\text { Follow Up }\end{array}$ & $\begin{array}{c}\text { Pretest }- \\
\text { Posttest }\end{array}$ & $\begin{array}{c}\text { Pretest- } \\
\text { Follow } \\
\text { Up }\end{array}$ & $\begin{array}{c}\text { Posttest- } \\
\text { Follow } \\
\text { Up }\end{array}$ \\
\hline 1 & 12 & 9 & -3 & 1 & 3 & 2 \\
\hline 2 & 4 & 6 & 2 & -2 & -5 & -3 \\
\hline 3 & 9 & 7 & -2 & -3 & -3 & 0 \\
\hline 4 & 3 & 14 & 11 & 4 & 2 & -2 \\
\hline 5 & 3 & -2 & -5 & 2 & 1 & -1 \\
\hline 6 & 1 & 0 & -1 & -3 & -1 & 2 \\
\hline 7 & 3 & 8 & 5 & -1 & -2 & -1 \\
\hline 8 & 3 & 0 & -3 & 4 & -2 & -6 \\
\hline 9 & 8 & 17 & 9 & 2 & 5 & 3 \\
\hline 10 & 4 & 2 & -2 & & & \\
\hline $\begin{array}{c}M e \\
\text { an }\end{array}$ & 5,0 & 6,1 & 1,1 & 0,44 & $-0,22$ & $-0,67$ \\
\hline
\end{tabular}

TABLE VI. GAIN SCORE OF POSITIVE AFFECT IN EXPERIMENT AND CONTROL GROUP

\begin{tabular}{|c|c|c|c|c|c|c|}
\hline \multirow{3}{*}{$\begin{array}{c}\text { Sub } \\
\text { Ject }\end{array}$} & \multicolumn{3}{|c|}{ Gain Score Experiment } & \multicolumn{3}{c|}{ Gain Score Control } \\
\cline { 2 - 7 } & $\begin{array}{c}\text { Pretest- } \\
\text { Posttest }\end{array}$ & $\begin{array}{c}\text { Pretest- } \\
\text { Follow } \\
\boldsymbol{U p}\end{array}$ & $\begin{array}{c}\text { Posttest- } \\
\text { Follow } \\
\boldsymbol{U p}\end{array}$ & $\begin{array}{c}\text { Pretest- } \\
\text { Posttest }\end{array}$ & $\begin{array}{c}\text { Pretest- } \\
\text { Follow } \\
\boldsymbol{U p}\end{array}$ & $\begin{array}{c}\text { Posttest- } \\
\text { Follow } \\
\text { Up }\end{array}$ \\
\hline 1 & 10 & 5 & -5 & -1 & 1 & 2 \\
\hline 2 & 5 & 4 & -1 & 0 & -1 & -1 \\
\hline 3 & 6 & 3 & -3 & -6 & -6 & 0 \\
\hline 4 & 2 & 4 & 2 & 4 & 3 & -1 \\
\hline 5 & 3 & 1 & -2 & 3 & 3 & 0 \\
\hline 6 & -1 & -1 & 0 & -4 & 0 & 4 \\
\hline 7 & 0 & 5 & 5 & 0 & -2 & -2 \\
\hline 8 & 0 & -2 & -2 & 2 & -2 & -4 \\
\hline 9 & 6 & 7 & 1 & -3 & -2 & 1 \\
\hline 10 & 3 & 0 & -3 & & & \\
\hline $\mathrm{Me}$ & 3,4 & 2,6 & $-0,8$ & $-0,56$ & $-0,67$ & $-0,11$ \\
\hline $\mathrm{An}$ & & & & & & \\
\hline
\end{tabular}

TABLE VII. GAIN SCORE OF NEGATIVE AFFECT IN EXPERIMENT AND CONTROL GROUP

\begin{tabular}{|c|c|c|c|c|c|c|}
\hline \multirow{4}{*}{ Subject } & \multicolumn{3}{|c|}{ Gain Score Experiment } & \multicolumn{3}{c|}{ Gain Score Control } \\
\cline { 2 - 7 } & $\begin{array}{c}\text { Pre } \\
\text { test- } \\
\text { Post } \\
\text { test }\end{array}$ & $\begin{array}{c}\text { Pre } \\
\text { test- } \\
\text { Follow } \\
\text { Up }\end{array}$ & $\begin{array}{c}\text { Post } \\
\text { test- } \\
\text { Follow } \\
\text { Up }\end{array}$ & $\begin{array}{c}\text { Pre } \\
\text { test- } \\
\text { Post } \\
\text { test }\end{array}$ & $\begin{array}{c}\text { Pre } \\
\text { test- } \\
\text { Follow Up }\end{array}$ & $\begin{array}{c}\text { Post } \\
\text { test- } \\
\text { Follow } \\
\text { Up }\end{array}$ \\
\hline 1 & -2 & -4 & -2 & -2 & -2 & 0 \\
\hline 2 & 1 & -2 & -3 & 2 & 4 & 2 \\
\hline 3 & -3 & -4 & -1 & -3 & -3 & 0 \\
\hline 4 & -1 & -10 & -9 & 0 & 1 & 1 \\
\hline 5 & 0 & 3 & 3 & 1 & 2 & 1 \\
\hline 6 & -2 & -1 & 1 & -1 & 1 & 2 \\
\hline 7 & -3 & -3 & 0 & 1 & 0 & -1 \\
\hline 8 & -3 & -2 & 1 & -2 & 0 & 2 \\
\hline 9 & -2 & -10 & -8 & -5 & -7 & -2 \\
\hline 10 & -1 & -2 & -1 & & & \\
\hline Mean & $-1,6$ & $-3,5$ & $-1,9$ & -1 & $-0,44$ & 0,56 \\
\hline
\end{tabular}

\section{B. Test Assumption}

The assumption test was conducted to find out whether the hypothesis test in this study use parametric or non-parametric statistics.

\section{- Normality Test}

Normality test used Kolmogorov-Smirnov and the significance level used 5\% (0.05). Data was obtained from the experiment and control group in pretest, posttest and follow up. The balance affect scores in this study can be seen in the table below:

TABLE VIII. NORMALITY TEST RESULT OF KOSMOGOROV-SMIRNOV TEST

\begin{tabular}{|c|c|c|c|c|c|c|}
\hline & $\begin{array}{c}\text { Control } \\
\text { Pre }\end{array}$ & $\begin{array}{c}\text { Control } \\
\text { post }\end{array}$ & $\begin{array}{c}\text { Control } \\
\text { follow }\end{array}$ & $\begin{array}{c}\text { Exp } \\
\text { erim } \\
\text { ent } \\
\text { pre }\end{array}$ & $\begin{array}{c}\text { Experi } \\
\text { ment } \\
\text { post }\end{array}$ & $\begin{array}{c}\text { Experi } \\
\text { ment } \\
\text { follow }\end{array}$ \\
\hline $\mathrm{N}$ & 9 & 9 & 9 & 10 & 10 & 10 \\
\hline $\begin{array}{c}\text { Kolmogoro } \\
\text { v-Smirnov } \\
\mathrm{Z}\end{array}$ & .773 & .439 & .500 & .558 & .926 & .709 \\
\hline $\begin{array}{c}\text { Asymp. } \\
\text { Sig. (2- } \\
\text { tailed) }\end{array}$ & .589 & .990 & .964 & .915 & .358 & .696 \\
\hline
\end{tabular}

The value of Kolmogorov-Smirnov $\mathrm{Z}$ pretest of control group is 0.773 , posttest of control group is 0.439 , and follow-up of control group is 0,500 . While pretest of experiment group is 0,558 , posttest of experiment group is 0,926 , and follow up of control group is 0,709 . Then it can be concluded that the data on pretest, posttest, and follow up of both control and experiment groups is normally distributed

- Homogeneity Test

Homogeneity test used t test technique (Levene's Test) with the help of SPSS for MS Windows version 21. The level of significance used $5 \%(0.05)$. 
TABLE IX. HOMOGENEITY TEST OF BALANCE AFFECT

\begin{tabular}{|c|c|c|c|c|}
\hline & $\begin{array}{c}\text { Levene } \\
\text { Statistic }\end{array}$ & df1 & df2 & Sig. \\
\hline Pretest & .416 & 1 & 17 & .528 \\
\hline Posttest & .173 & 1 & 17 & .683 \\
\hline Follow up & .598 & 1 & 17 & .450 \\
\hline
\end{tabular}

The obtained significance is $0.528,0.683$, and 0.450 . If the values are more than 0.05 , it can be concluded that the experiment and control groups have the same variant.

\section{Hypotesis Test}

Independent Sample T Test did hypothesis test on gained score from two independent samples. Independent Sample T Test was conducted with the purpose to know whether there is difference in both experiment and control groups, so it can be known the influence of the gratitude training towards the increasing of balance affect. The test results on the impact of the gratitude training to balance affect in the experiment and control groups can be seen in the following table.

TABLE $\mathrm{X}$. INDEPENDENT SAMPLE T TEST OF BALANCE AFFECT IN EXPERIMENT AND CONTROL GROUP

\begin{tabular}{|c|c|c|c|c|c|}
\hline & Group & $\mathrm{N}$ & Mean & $\begin{array}{c}\text { Std. } \\
\text { Deviation }\end{array}$ & $\begin{array}{c}\text { Std. Error } \\
\text { mean }\end{array}$ \\
\hline \multirow{2}{*}{$\begin{array}{c}\text { Gain } \\
\text { prepost }\end{array}$} & Control & 9 & .44 & 2.789 & .930 \\
\cline { 2 - 6 } & Experiment & 10 & 5.00 & 3.464 & 1.095 \\
\hline \multirow{2}{*}{$\begin{array}{c}\text { Gain } \\
\text { prefollow }\end{array}$} & Control & 9 & -.22 & 3.193 & 1.064 \\
\cline { 2 - 6 } & Experiment & 10 & 6.10 & 6.244 & 1.975 \\
\hline \multirow{2}{*}{$\begin{array}{c}\text { Gain } \\
\text { postfollow }\end{array}$} & Control & 9 & -.67 & 2.828 & .943 \\
\cline { 2 - 6 } & Experiment & 10 & 1.10 & 5.486 & 1.735 \\
\hline
\end{tabular}

TABLE XI. INDEPENDENT SAMPLE T TEST OF BALANCE AFFECT IN EXPERIMENT AND CONTROL GROUP

\begin{tabular}{|c|c|c|c|c|c|c|}
\hline & & \multicolumn{2}{|c|}{$\begin{array}{c}\text { Levene's Test } \\
\text { for Equality of } \\
\text { Variances }\end{array}$} & \multicolumn{3}{|c|}{$\begin{array}{l}\text { t-test for Equality of } \\
\text { Means }\end{array}$} \\
\hline & & $\mathrm{F}$ & Sig. & $\mathrm{t}$ & df & $\begin{array}{c}\text { Sig. } \\
(2- \\
\text { tailed }) \\
\end{array}$ \\
\hline \multirow{2}{*}{$\begin{array}{l}\text { GAIN } \\
\text { PRE } \\
\text { POST }\end{array}$} & $\begin{array}{c}\text { Equal } \\
\text { variances } \\
\text { assumed } \\
\end{array}$ & .329 & .574 & -3.133 & 17 & .006 \\
\hline & $\begin{array}{c}\text { Equal } \\
\text { variances not } \\
\text { assumed }\end{array}$ & & & -3.171 & $\begin{array}{c}16.81 \\
8\end{array}$ & .006 \\
\hline \multirow{2}{*}{$\begin{array}{c}\text { GAIN } \\
\text { PRE } \\
\text { FOLLOW }\end{array}$} & $\begin{array}{c}\text { Equal } \\
\text { variances } \\
\text { assumed }\end{array}$ & 3.170 & .093 & -2.728 & 17 & .014 \\
\hline & $\begin{array}{c}\text { Equal } \\
\text { variances not } \\
\text { assumed } \\
\end{array}$ & & & -2.818 & $\begin{array}{c}13.68 \\
9\end{array}$ & .014 \\
\hline \multirow{2}{*}{$\begin{array}{c}\text { GAIN } \\
\text { POST } \\
\text { FOLLOW }\end{array}$} & $\begin{array}{c}\text { Equal } \\
\text { variances } \\
\text { assumed } \\
\end{array}$ & 5.086 & .038 & -.866 & 17 & .398 \\
\hline & $\begin{array}{c}\text { Equal } \\
\text { variances not } \\
\text { assumed }\end{array}$ & & & -.895 & $\begin{array}{c}13.75 \\
1\end{array}$ & .386 \\
\hline
\end{tabular}

The table 10 shows that the average of the experiment group rank is 5.00 at the pretest-posttest gained score, 6.10 at the pretest-follow-up gained score, and 1.10 at the posttestfollow up gained score. The average rank for the control group is 0.44 at the pretest-posttest gained score, -0.22 at the gained score of pretest-follow-up, and -0.67 at the posttest-follow up gained score. Before looking at the t-value, first look at the value of $\mathrm{F}$ and the significance in Levene's test column. As seen in the column of table 11 , the value of $F$ is 0.329 and significance is $0.574(>0.05)$ for the pretest-posttest gained score, $F$ is 3.170 and significance is 0.093 ( $p>0.05$ ) for pretestfollow-up gained score, and $\mathrm{F}$ is 5.086 and significance is $0.038(\mathrm{p}<0.05)$ for the posttest-follow-up gained score, so the pretest-posttest and pretest-follow up gained scores are assumed to have equal variants while the posttest-follow-up gained score is not assumed to have equal variants.

From the Table 11 above, it can be seen the t-value is 3.133 for pretest-posttest while the value of t-table is 1.740 with probability (p) significance is 0.003 (one-way test) or $\mathrm{p}<0.05$. The $t$-value is greater than the value of t-table with $p<0.05$ so there is a difference mean score of balance affect between the experiment and control groups shortly after the training. It means that there is positive influence of gratitude training to increase the balance effect of the poor resident shortly after the training.

The persistence of this positive influence can be seen from the result of pretest-follow-up calculation with $t$-value equal to 2,728 while t-table value is 1,740 with probability (p) significance 0,007 (one way test). The t-value is greater than the value of t-table with (p) $0.007(\mathrm{p}<0.05)$, it means that there is a different mean score of balance affect between the experiment and control groups.

The result of comparing posttest-follow up between experiment and control groups, the t-value is 0.895 while ttable value is 1,761 (equal variances not assumed; df $=14$ ) with probability (p) significance is 0,193 (One-way test). The tvalue is smaller than t-table with (p) 0.193 ( $>0.05$ ), it means that there is no different mean of balance affect between experiment and control groups from posttest to follow up. Based on Table 10 it can be seen that there is a decreasing mean score in control group and improvement in experiment group at posttest-follow up. The t test results in Table 11 shows that the decrease as well as the increase occurred in both groups during posttest-follow up is not significant. This indicates that the positive influence of gratitude training provides a relatively stable increasing in the balance affect because the subject is still in the similar balance effect of pretest-follow up condition. It means the subjects have to practice the activities given in the training into daily life for a continuous significant increase in the experiment group.

Based on the above explanation, it can be concluded that there is a positive influence of the gratitude training on the increasing of the poor resident balance affect and it is relatively stable.

The total score of SPANE which is the balance affect obtained by subtract the positive affect score with negative affect one, this study proved the higher balance affect which can be explained by three possibilities, i.e. (1) the higher 
positive affect score and the lower negative affect score meaning that the gratitude training has an effect on both affects; (2) the extremely high of the positive affect score while the negative affect score is stagnant meaning the gratitude training only has an effect on positive affect; or (3) the positive affect score is stagnant but on the other hand the negative affect score is lower meaning the gratitude training only has an effect on negative affect.

Independent Sample T Test is required to test the difference of positive and negative affect between experiment and control groups. A two-tailed test is applied to the calculation because the increase of balance affect could occurs because of the first logical possibility (gratitude training has effect of both affects), so the gratitude training gives different direction to influence each affect (positive and negative).

TABLE XII. INDEPENDENT SAMPLE T TEST IN POSITIVE AFFECT OF EXPERIMENT AND CONTROL GROUP

\begin{tabular}{|c|c|c|c|c|c|}
\hline & Group & $\mathrm{N}$ & Mean & $\begin{array}{c}\text { Std. } \\
\text { Deviation }\end{array}$ & $\begin{array}{c}\text { Std. } \\
\text { Error } \\
\text { mean }\end{array}$ \\
\hline \multirow{2}{*}{$\begin{array}{c}\text { Gain } \\
\text { prepost }\end{array}$} & Control & 9 & -.56 & 3.321 & 1.107 \\
\cline { 2 - 6 } & Experiment & 10 & 3.40 & 3.406 & 1.077 \\
\hline Gain pre & Control & 9 & -.67 & 2.828 & .943 \\
\cline { 2 - 6 } Follow & Experiment & 10 & 2.60 & 2.951 & .933 \\
\hline Gain post & Control & 9 & -.11 & 2.315 & .772 \\
\cline { 2 - 6 } Follow & Experiment & 10 & -.80 & 2.898 & .917 \\
\hline
\end{tabular}

TABLE XIII. INDEPENDENT SAMPLE T TEST IN POSITIVE AFFECT OF EXPERIMENT AND CONTROL GROUP

\begin{tabular}{|c|c|c|c|c|c|c|}
\hline & & \multicolumn{2}{|c|}{$\begin{array}{l}\text { Levene's test } \\
\text { for equality } \\
\text { of variances }\end{array}$} & \multicolumn{3}{|c|}{ T-test for equality of means } \\
\hline & & $\mathrm{F}$ & Sig. & $\mathrm{T}$ & Df & $\begin{array}{c}\text { Sig. } \\
\text { (2-tailed) }\end{array}$ \\
\hline \multirow{2}{*}{$\begin{array}{l}\text { Gain } \\
\text { pre } \\
\text { Post }\end{array}$} & $\begin{array}{c}\text { Equal variances } \\
\text { assumed }\end{array}$ & $\begin{array}{c}.00 \\
5\end{array}$ & .943 & -2.558 & 17 & .020 \\
\hline & $\begin{array}{c}\text { Equal variances } \\
\text { not assumed }\end{array}$ & & & -2.561 & $\begin{array}{l}16 . \\
874\end{array}$ & .020 \\
\hline \multirow{2}{*}{$\begin{array}{c}\text { Gain } \\
\text { pre } \\
\text { Follow }\end{array}$} & $\begin{array}{c}\text { Equal variances } \\
\text { assumed }\end{array}$ & $\begin{array}{c}.22 \\
5\end{array}$ & .641 & -2.457 & 17 & .025 \\
\hline & $\begin{array}{l}\text { Equal variances } \\
\text { not assumed }\end{array}$ & & & -2.462 & $\begin{array}{l}16 . \\
919\end{array}$ & .025 \\
\hline \multirow[b]{2}{*}{$\begin{array}{c}\text { Gain } \\
\text { post } \\
\text { Follow }\end{array}$} & $\begin{array}{c}\text { Equal variances } \\
\text { assumed }\end{array}$ & $\begin{array}{c}.59 \\
0 \\
\end{array}$ & .453 & .568 & 17 & .578 \\
\hline & $\begin{array}{c}\text { Equal variances } \\
\text { not assumed }\end{array}$ & & & .575 & $\begin{array}{c}16 . \\
791\end{array}$ & .573 \\
\hline
\end{tabular}

Table 12 shows that the average of the experiment group ranks is 3.40 at the pretest-posttest gain score, 2.60 at the pretest-follow-up gained score, and -0.80 at the posttest-follow up gained score. The average rank for the control group is -0.56 at the pretest-posttest gained score, -0.67 at the pretest-followup gained score, and -0.11 at the posttest-follow up gained score. Before looking at the t-value, first look at the value of $\mathrm{F}$ and the significance in Levene's test column. As seen in the column of the Table 13, the value of $F$ is 0.005 and the significance is $0.943(\mathrm{p}>0.05)$ for the pretest-posttest gained score, $\mathrm{F}$ is 0.225 and significance is $0.641(\mathrm{p}>0.05)$ for pretestfollow-up gained score, and $\mathrm{F}$ is 0,590 and significance is 0.453 ( $p>0.005$ ) for posttest-follow-up gained score, so the three scores are equivalent which is called equal variances assume in statistical term.

From the Table 13 above, it can be seen that t-value is 2.558 for pretest-posttest while the value of t-table is 2.110 with probability (p) significance is 0.020 (two-ways test). The $\mathrm{t}$-value is greater than $\mathrm{t}$-table with (p) 0.020 or $\mathrm{p}<0.05$ then there is difference of mean positive affect score between experiment and control group immediately after training meaning that there is a positive influence of gratitude training toward increasing positive affect of the poor resident shortly after the training.

The persistence of this positive influence can be seen from the result of pretest-follow-up calculation with t-value equals to 2.457 while t-table value is 2.110 with probability (p) 
significance is 0,0125 . The value of $\mathrm{t}$-value is greater than $\mathrm{t}$ table and $\mathrm{p}<0.05$, it means that there is a difference of mean of positive affect score between experiment and control groups.

The result of posttest-follow up between experiment and control groups t-value is 0.568 while t-table value is 1,740 with probability (p) significance is 0.289 (two-ways test). The $t-$ value is smaller than $t$-table with $p>0.05$, it means that there is no difference of positive affect score between experiment and control groups from posttest to follow up. Based on Table 12 it can be seen that there is a decreasing mean score on both control and experiment groups at posttest-follow up. The t-test results in Table 13 shows no significance, so the decreasing that occurred in both groups during posttest-follow up was not significant. This suggests that the positive impact of gratitude training provides a relatively stable increasing positive affect because the subject is still in the similar condition of positive affect (pretest-follow up) so that each subject needs to retain the activities obtained during training into daily life for a continuous significant increasing in the experiment group.

Furthermore, it can be concluded that there is a positive influence of gratitude training on the positive affect of the poor resident and it is relatively stable.

Table 14 shows that the average rank of the experiment group is -1.60 at the pretest-posttest gained score, -3.50 at the gained score of pretest-follow-up, and -1.90 at the posttestfollow-up gained score. The average rank for the control group is -1.00 at the pretest-posttest gained score, -0.44 at the gained score pretest-follow up, and 0.56 at the posttest-follow-up gained score. Before looking at the t-value, first look at the value of $\mathrm{F}$ and the significance in Levene's test column of the table 15. As seen in the column, the value of $F$ is 2,407 and the significance is $0.139(\mathrm{p}>0.05)$ for the pretest-posttest gained score, $F$ score is 0.159 and significance is $0.695(\mathrm{p}>0.05)$ for pretest-follow-up gained score, and $\mathrm{F}$ is 4.247 and the significance is $0.055(\mathrm{p}>0.05)$ for posttest-follow-up gained score, so that the three score is equivalent. The result of the statistical test of t-value is 0.717 and probability (p) of significance is 0.241 (two-tailed test) for pretest-posttest, tvalue is 1.837 and probability (p) significance is 0.042 for pretest-follow up, and t-value is 1.792 and probability (p) significance is 0.045 for posttest-follow up and the t- table is 2.110 .

Based on the above calculation, t-value is 0.717 , smaller than $\mathrm{t}$-table and probability (p) $0.241(\mathrm{p}>0.05)$ for pretestposttest, $\mathrm{t}$-value is 1.837 smaller than $\mathrm{t}$ - table and probability (p) is 0.042 ( $p>0.05$ ) for pretest-follow up, and t-value is 1,792 smaller than t-table and probability (p) is 0,091 bigger than $\alpha=$ 0,05 for posttest-follow up. It means there is no difference mean negative affect score between experiment and control group from pretest to posttest, pretest to follow up, and posttest to follow-up. Furthermore, it can be concluded that there is no negative impact of the gratitude training on the decreasing of negative affect of the poor resident.

Based on the above calculation results, it can be illustrated that there is an increasing of positive affect score in the experimental group that can be different with control group but not accompanied by significant decreasing of negative affect. Hence, the increasing of balance affect in this study is due to the second logical possibility, so the gratitude training has effect only on the positive affect. This illustrates that the difference mean of the balance affect score between experiment and control group occurs because of the difference of positive affect mean scores between experiment and control group. Therefore, it can be concluded that there is a positive influence of gratitude training on increasing the balance effect of the poor resident due to an increase in positive affect and it is relatively stable.

Furthermore, to see whether the increase in positive affect on the experiment group was significant both immediately after the training and when the subject had undergone daily life, an analysis was performed by Paired Sample T Test. Test results can be seen in the following table:

TABLE XVI. PAIRED SAMPLE T TEST IN BALANCE AFFECT ON EXPERIMENT GROUP

\begin{tabular}{|c|c|c|c|c|}
\hline & & $\mathrm{t}$ & $\mathrm{Df}$ & Sig. (2-tailed) \\
\hline Pair 1 & Pretest - Posttest & -4.564 & 9 & .001 \\
\hline Pair 2 & Pretest - Follow up & -3.089 & 9 & .013 \\
\hline Pair 3 & Posttest - Follow up & -.634 & 9 & .542 \\
\hline
\end{tabular}

TABLE XVII. PAIRED SAMPLE T TEST IN BPOSITIVE AFFECT ON EXPERIMENT GROUP

\begin{tabular}{|c|c|c|c|c|}
\hline & & $\mathrm{t}$ & $\mathrm{df}$ & Sig. (2-tailed) \\
\hline Pair 1 & Pretest - Posttest & -3.157 & 9 & .012 \\
\hline Pair 2 & $\begin{array}{c}\text { Pretest - Follow } \\
\text { up }\end{array}$ & -2.786 & 9 & .021 \\
\hline Pair 3 & $\begin{array}{c}\text { Posttest - Follow } \\
\text { up }\end{array}$ & .873 & 9 & .405 \\
\hline
\end{tabular}

Statistical test results Table 16 on pretest-posttest obtained $t$ count-value is 4.564 and probability (p) significance is 0.001 with t-table is 2.262 . The statistical test results show that $\mathrm{t}$ value is greater than t-table and the probability ( $p)$ is smaller than $\alpha=0.05$, which means there is a significant difference between the mean score of the pre-test affect and the posttest of the experiment group.

The persistence of this significant difference can be seen from the results of pretest-follow-up calculations that obtained $\mathrm{t}$-value is 3.089 and probability (p) significance is 0.013 with ttable is 2.262. The result of the statistical test shows that $t-$ value is greater than t-table and the probability (p) is smaller than $\alpha=0.05$ which means there is difference significant between the mean score of the pre-test and pre-test affect score on the experiment group.

The result of posttest-follow up calculation on experiment group get t-value 0,634 and probability (p) significance is 0,542 with t-table is 2,262 . The result of statistical test shows that $\mathrm{t}$-value is smaller than t-table and the probability $(\mathrm{p})$ is greater than $\alpha=0,05$, it means there is no significant difference of balance affect mean score between posttest and follow up in 
experiment group. Based on Table 16 it can be seen that the increasing (negative t-value) mean score from posttest to follow up that occurred in experiment group is not significant. This suggests that the effectiveness of the gratitude training provides a relatively stable increasing in the balance affect since the subject is still in the same pretest-follow up condition because the increasing is not significant.

Based on the data explanation above, it can be concluded that there is a significant difference of balance affect score between before and after training, which means the effect of gratitude training in improving the balance effect on the poor resident is effective and relatively stable.

Statistical test results in Table 17 on pretest-posttest obtained t-value equal to 3.157 and probability (p) significance is 0.012 with t-table is 2.262 . The statistical test results show that t-value is greater than t-table and the probability (p) is smaller than $\alpha=0.05$, it means there is a significant difference between the mean score of positive affect before the training (pretest) and shortly after the posttest of the experiment group.

The persistence of this significant difference can be seen from the result of pretest-follow-up calculation which get $\mathrm{t}$ value equal to 2,786 and probability (p) significance is 0,021 with t-table is 2,262. The results of statistical tests show that $t-$ value is greater than t-table and the probability (p) is smaller than $\alpha=0.05$, it means there is a significant difference between the mean of positive affect pre-test score before the training (pretest) and after the follow up of the experiment group. .

The result of posttest-follow up calculation on experiment group got t-value equal to 0,873 and probability (p) significance is 0,405 with t-table 2,262. The result of statistic test shows that $\mathrm{t}$-value smaller than $\mathrm{t}$-table and probability $(\mathrm{p})$ is bigger than $\alpha=0,05$, it means there is no significant mean difference of positive affect score between posttest and follow up on experiment group. Based on Table 17 it can be seen that the decreasing (positive t-value) mean score from posttest to follow up that occurred in experiment group is not significant. This suggests that the effectiveness of the gratitude training provides a relatively stable increasing in the balance affect because the subject is still in the same balance affect condition (pretest-follow up significantly) because the decreasing is not significant.

Based on the data explanation above, it can be concluded that there is significant mean difference of positive affect score between before and after training, which means the effectively of gratitude training in improving positive effects on the poor resident is relatively stable.

Based on the data explanation above, it can be concluded that the effectively of gratitude training increases the balance affect caused by the increasing of positive effects on the poor resident and is relatively stable so that each subject needs to maintain the activities gained during the training into daily life.

The researchers then also conducted Paired Sample T Test on balance affect score and positive affect of control group during pretest, posttest, and follow up to see if the increasing of balance and positive affect also occurred in control group.
TABLE XVIII. PAIRED SAMPLE T TEST IN BALANCE AFFECT ON CONTROL GROUP

\begin{tabular}{|c|c|c|c|c|}
\hline & & t & Df & $\begin{array}{c}\text { Sig. (2- } \\
\text { tailed) }\end{array}$ \\
\hline Pair 1 & Pretest - Posttest & -.478 & 8 & .645 \\
\hline Pair 2 & Pretest - Follow up & .209 & 8 & .840 \\
\hline Pair 3 & Posttest - Follow up & .707 & 8 & .500 \\
\hline
\end{tabular}

TABLE XIX. PAIRED SAMPLE T TEST IN POSITIVE AFFECT ON CONTROL GROUP

\begin{tabular}{|c|c|c|c|c|}
\hline & & $\mathrm{t}$ & Df & $\begin{array}{c}\text { Sig. (2- } \\
\text { tailed) }\end{array}$ \\
\hline Pair 1 & Pretest - Posttest & $\begin{array}{c}.50 \\
2\end{array}$ & 8 & .629 \\
\hline Pair 2 & Pretest - Follow up & $\begin{array}{c}.70 \\
7\end{array}$ & 8 & .500 \\
\hline Pair 3 & Posttest - Follow up & $\begin{array}{c}.14 \\
4\end{array}$ & 8 & .889 \\
\hline
\end{tabular}

The results of the statistical tests Table 18 shows t-value equal to 0.478 and probability (p) significance is 0.645 (twotailed test) for pretest-posttest, t-value equal to 0.209 and probability (p) significance is 0.840 (two-tailed test) for pretest-follow up, and t-value equal to 0.707 and probability (p) significance is 0.500 (two-tailed test) for posttest-follow up and has t-table 2.306 .

Based on the above calculation obtained t-value equal to 0.478 smaller than t-table and probability (p) 0.645 greater than $\alpha=0.05$ for pretest-posttest, $t$-value equal to 0.209 smaller than t-table and probability (p) 0.840 greater than $\alpha=0,05$ for pretest-follow up, and t-value equal to 0,707 less than t-table and probability (p) 0,500 bigger than $\alpha=0,05$ for posttestfollow up. Furthermore, it can be concluded that there is no increasing in effect on control group during pretest-posttest, pretest-follow up, and posttest-follow up.

The result of the statistical test-table 19 shows t-value equal to 0,502 and probability (p) significance is 0.629 (two-tailed test) for pretest-posttest, t-value equal to 0.707 and probability (p) significance is 0.500 (two-tailed test) for pretest-follow up, and $\mathrm{t}$-value equal to 0.144 and probability (p) significance is 0.889 (two-tailed test) for posttest-follow up and has t-table 2.306 .

Based on the above calculation obtained t-value equal to 0,502 smaller than t-table and probability (p) 0.629 bigger than $\alpha=0.05$ for pretest-posttest, $t$-value equal to 0.707 smaller than t-table and probability (p) 0,500 bigger than $\alpha=0,05$ for pretest-follow up, and t-value equal to 0,144 smaller than $\mathrm{t}$ table and probability (p) 0,889 bigger than $\alpha=0,05$ for pretestposttest. Furthermore, it can be concluded that there is no increasing of positive affect score in control group during pretest-posttest, pretest-follow up, and posttest-follow up.

This illustrates that the increasing in the balance affect score caused by the positive affect increasing in the experiment group did not occur in the control group because of the absence of treatment on the control group. 


\section{DISCUSSION}

Based on the data presented in Figure 2, it can be seen that the average of the balance affect score of the experiment group has increased from pretest, posttest and follow up. This is different when it is compared to control group which is relatively up from pretest to posttest, and is relatively down from pretest to follow up. Gained score of pretest-posttest data is then tested by Independent Sample T Test in which the difference of balance affect score between experiment and control group obtained, it means that there is an increase of balance affect score in experiment group, meaning there is a positive influence of gratitude training toward increasing balance affect (affective component of SWB) in the experiment group immediately after training (t-value $3.133>\mathrm{t}$-table 1.740 and p $0.003<0.05$ ) as seen in Table 11. This positive effect is relatively stable as seen from the results of the Independent Sample T Test pretest-follow up that obtained t-value of $2.728>$ t-table 1.740 and (p) $0.007<0.05$ in Table 11.

The results of the Independent Sample $\mathrm{T}$ Test posttestfollow up test between the experiment and control group (tvalue $0.895<$ t-table 1.761 and p $0.193>0.05)$ as seen in Table 11 occur because no significant score changes in both groups when the posttest to follow up and the subject is still in the same affect condition (significant at the time of pretest to follow-up), this illustrates that the training of gratitude in this study has a positive effect on the increase of the relatively stable balance affect. Furthermore, based on the explanation, it can be concluded that there is a positive influence of gratitude training on improving the balance effect of the poor resident and it is relatively stable, so that each subject needs to maintain applying the activities gained during the training into daily life.

Increased balance affect as happened in this study can occur because of three possibilities, namely (1) the higher the positive affect score and the lower the negative affect score means that the training of gratitude has an effect on both affects; (2) the higher the positive affect score and the negative affect score is not lower means the training of gratitude only has an effect to positive affect; or (3) the positive affect score is not higher and the negative affect score is lower means that the training of gratitude only has an effect of negative affect.

Based on this fact, it is necessary to use Independent Sample $\mathrm{T}$ Test to test the difference of positive and negative affect score between the two groups. A two-tailed test was applied to the second Independent Sample T Test based on the likelihood that an increase in balance affect occurs because the first logical possibility (gratitude training has an effect of both affects), so that the training of gratitude gives different influence on each side of each affect (positive and negative).

Based on the data presented in Figure 3, it can be seen that the average graph of positive affect scores of the experiment group has increased from pretest to posttest and decreases during follow up. This is different compared to the control group which is relatively decreased from pretest, posttest and to follow-up. In Figure 4 it can be seen that the average graph of the experiment group negative affect score decreases from pretest to posttest and to follow up. This is different compared to the control group which is relatively decreased from pretest to posttest but increases during follow up.
Gained score of pretest-posttest positive affect data then was tested by Independent Sample T Test and the difference of positive affect score between experiment and control group gained, meaning that there is positive influence of gratitude training toward positive affect increasing in experiment group immediately after training $(\mathrm{t}$-value $2,558>\mathrm{t}$-table 2,110 and $\mathrm{p}$ $0,020<0.05)$ as seen in Table 13. This positive influence is relatively stable which can be seen from the results of the Independent Sample T Test pretest-follow up calculation with $\mathrm{t}$-value 2,457> t-table 2,110 and (p) $0.025<0.05$ as shown in Table 13.

The results of the Independent Sample T Test posttestfollow up test between the experiment and control group (tvalue $0.568<\mathrm{t}$-table 2.110 and $\mathrm{p} 0.578>0.05$ ) as seen in Table 13 occur because no significant score change in both groups when posttest to follow-up and Subject are still in the same positive affect condition (significant at the time of pretest to follow-up), this illustrates that the training of gratitude in this study has a positive effect on a relatively positive increasing on positive affect. Furthermore, it can be concluded that there is a positive effect of gratitude training on improving the positive affect of the poor resident and is relatively stable, so that each subject needs to maintain applying the activities gained during the training into daily life.

Different things happen in statistical tests of Independent Sample $\mathrm{T}$ Test gained score pretest-posttest negative affect with t-value $0.717<\mathrm{t}$-table 2,110 and (p) $0,483>0.05$ for pretest-posttest, t $1.837<t$-table 2,110 and (p) $0.084>0.05$ for pretest to follow-up, and 1,792 $\mathrm{t}<\mathrm{t}$-table 2,110 and (p) 0.091> 0.05 for posttest-follow-up as shown in table 15 . Based on the calculations above were obtained t-value 0.717 smaller than ttable and the probability (p) 0,483 greater than $\alpha=0.05$ for the pretest-posttest, $\mathrm{t} 1.837$ is smaller than $\mathrm{t}$-table and the probability (p) 0,084 greater than $\alpha=0.05$ for pretest-follow up, and $\mathrm{t}$-value 1.792 less than $\mathrm{t}$-table and the probability (p) 0.091 greater than $\alpha=0.05$ for the posttest-follow-up. It means that there is no difference negative affect score between experiment and control groups from pretest to posttest, pretest to follow up, and posttest to follow up. Furthermore, it can be concluded that there is no negative influence of the training of gratitude on the decreasing of negative affect of the poor resident.

Based on the above calculation it can be seen that there is an increase of positive affect score in experiment group which can be differentiated within control group but not accompanied by significant decrease of negative affect score. Thus, the increase of the balance affect in this study occurs because of the second logical possibility (gratitude training only has an effect on positive affect). Thus, the difference in balance affect occurs because of the difference in positive affect between the two groups. Therefore, it can be concluded that there is a positive influence of gratitude training on increasing the balance effect of the poor resident due to an increase in positive affect and it is relatively stable.

The increasing influence on experiment group was significant, and can be seen from the result of Paired Sample T Test of experiment group ( $\mathrm{t}$-value 4,564> t-table 2,262 and $\mathrm{p}$ $0.001 \quad(\mathrm{p}<0,05)$ which showed significant difference of 
experiment group balance score during pretest-posttest as in Table 16. This significant difference is relatively persistent $(\mathrm{t}-$ value $3.089>$ t-table 2.262 and p $0.013(\mathrm{p}<0.05)$ is evident of the Paired Sample T Test pretest-follow up experiment group.

The result of Paired Sample $\mathrm{T}$ Test posttest-follow up experiment group (t-value $0.634<\mathrm{t}$-table 2,262 and $\mathrm{p} 0,542>0$, 05) as shown in Table 16 occurred because no significant score change in experiment group at posttest to follow up although it is significant at the time of pretest to follow-up, it means that the training of gratitude in this study is effective towards a relatively stable increase of balance affect. Furthermore, based on the explanation, it can be concluded that there are significant differences occurred in the experiment group before and after treatment, It means that an effective gratitude training improves the balance effect on the poor resident and is relatively stable.

The increasing effect of affect in experiment group was caused by the positive affect increasing that happened significantly, it can be seen from the result of Paired Sample T Test of experiment group (t-value 3.157> t-table 2,262 and $\mathrm{p}$ $0,012<0,05)$. A significant difference between the positive affect scores in the experiment group during pretest-posttest as seen in Table 17. This significant difference is relatively stable in the experiment group (t-value 2.786> t-table 2.262 and $p$ $0.021<0.05)$ as evidenced by the Paired test Sample T Test pretest-follow up experiment group.

The results of Paired Sample T Test posttest-follow up in the experiment group (t-value $0.837<\mathrm{t}$-table 2.262 and $\mathrm{p}$ $0.405>0.05)$ as shown in Table 17 occurred due to the absence of significant changes score in the experiment group at the time of posttest to follow-up although significant at the time of pretest to follow-up, this means the gratitude training in this study has an effectiveness towards a relatively positive increasing in positive affect. Furthermore, based on the explanation it can be concluded that there are significant differences that occurred in the experiment group before and after treatment, that means effective gratitude training improves positive effects of the poor resident and is relatively stable.

Based on the above explanation, it can be concluded that an effective gratitude training improves the balance affect caused by the significant increase on positive affect of the poor resident and is relatively stable.

Significant increase in the rate of affects through the positive affect occurring in the experiment group did not occur in the control group, as seen in the Paired Sample T Test balance affect pretest-posttest test (t-value $0.478<\mathrm{t}$-table 2.306 and p 0.645>0.05), pretest-follow up (t-value $0.209<\mathrm{t}$-table 2.306 and $\mathrm{p} 0.840>0.05$ ), and posttest-follow up (t-value 0.707 $<$ t-table 2.306 and p 0,500>0.05) as shown in Table 18 and Test result Paired Sample T Test positive affect pretest-posttest (t-value 0,502<t-table 2,306 and p 0,629>0,05), pretest-follow up (t-value $0,707<\mathrm{t}$-table 2,306 and p 0,500>0,05), and posttest-follow up (t-value $0.144<\mathrm{t}$-table 2.306 and $\mathrm{p} 0.889>$ 0.05 ) as shown in Table 19. This is due to the absence of treatment in the control group.
All explanations of the above statistical test resulted an illustration that there is a difference in balance affect in the experiment and control groups between before and after training, meaning gratitude training has a positive effect on increasing balance affect which is the affective evaluation of subjective well-being. Increased balance affect occurs due to an increase in positive affect as described in the above statistical test results.

Based on the above calculation also obtained the result that the training of gratitude effectively improve the balance effect on the poor resident. In addition, as noted earlier, the positive influence and effectiveness of the training of gratitude on improving the balance affect provides a relatively stable improvement, so that each subject needs to maintain applying the activities gained during the training into daily life in order to increase continuous balance affect.

The results of this study are in line with Watkins's assertion that gratitude affects the emotions gained when the benefits received are viewed as a virtue [4]. The results showed that the increase in balance affect occurred due to the increase of positive affect. Gratitude training allows participants to experience more positive affect than negative affects. This is consistent with the results of the experimental studies of Emmons and McCullough who found that gratitude groups exhibit a more significant positive affect than the control group [4]. Emmons and McCullogh found that intervention through gratitude can increase the positive affect that are components of subjective wellbeing affects [5].

Watkins explains that $95 \%$ of study respondents who express gratitude have an impact on feelings of happiness [4]. The relationship between gratitude as an affective state with a happy state, is clearly evident with the relationship of gratitude in improving mood [4]. In particular, McCullough et al. [12] explains further that grateful people tend to experience more positive emotions more often, enjoying satisfaction in life, and more hopeful and less likely to experience depression, anxiety, and jealousy.

Gratitude gives positive affect and reduces negative affect [13] [14]. At this point, the training carried out has not succeeded to affect both affects because it only increases positive affect but does not reduce negative effects. This is due to the lack of activities in the training that emphasize the decrease in the frequency of negative effects. Thus, activities in the training are required not only positive affect induction but also negative affective reduction.

\section{REFERENCES}

[1] Diener, Ed and Katherine Ryan. "Subjective Well-Being: A General Overview." South African Journal of Psychology, vol. 39, pp. 391-406, 2009.

[2] Diener, Ed. "Subjective Well-being: The Science of Happiness and a Proposal for a National Index." American Psychologist, vol. 55, pp. 3443, 2000

[3] Eid, Michael and Randy J. Larsen. The Science of Subjective Well-Being. New York: The Guilford Press, 2008.

[4] Emmons, Robert A. and Michael E. McCullough. The Psychology of Gratitude. New York: Oxford University Press, 2004.

[5] Diener, Ed, Richard E. Lucas, and Christie Napa Scollon. "Beyond the hedonic treadmill: revising the adaptation theory of well-being". American Psychologist, vol. 61, pp. 305-314, 2006. 
[6] Diener, Ed. Assessing Well Being. New York: Springer, 2009.

[7] Diener, Ed. The Science of Well Being. New York: Springer, 2009.

[8] Seniati, L., Yulianto, A., and Setiadi, BN. Psikologi Eksperimen. Jakarta: PT. Indeks Silva, 2009.

[9] Johnson, David W. and Frank P. Johnson. Joining Together Group Theory and Group Skills 6th Ed. Unites State of America: A Viacom Company, 1997.

[10] Sugiyono. Statistika Untuk Penelitian. Bandung: Alfabeta, 2010.

[11] Priyatno, Duwi. Paham Analisa Statistik Data dengan SPSS. Yogyakarta: Mediakom, 2010

[12]McCullough, Michael. E., Robert A. Emmons, dan Jo-Ann Tsang. "The Grateful Disposition A Conceptual and Empirical Topography." Journal of Personality and Social Psychology. vol 82, pp. 112-127, 2002.

[13]McCullough, Michael E. and Emily L. Polak. "Is Gratitude An Alternative Materialsm?" Journal of Happiness Studies, vol.7, pp. 343$360,2006$.

[14]Lopez, Shane J. The Encyclopedia of Positive Psychology. United Kingdom: Blackwell Publishing Ltd, 2009.

[15]Ana Junca and Antonio Caetano. "Validation of the Flourishing scale and Scale of Positive and Negative Experience in Portugal". Springer Science and Business Media Social Indic Res, [Online] Available: DOI 10.1007/s11205-011-9938-y, 2011. 